\title{
Efektivitas Briket Bioarang Tabingga dan Tongkol Jagung sebagai Sumber Energi Alternatif
}

\author{
Finta Amalinda ${ }^{1 *}$, Nur Rismawati ${ }^{2}$ \\ ${ }^{1,2}$ Universitas Muhammadiyah Palu \\ *Email: fintaamalinda@unismuhpalu.ac.id
}

\begin{abstract}
One way to overcome the energy problem is to find alternative energy obtained from biomass. Central Sulawesi is one of the coconut producing regions. Coconut is processed to be made into coconut oil and copra. Waste from coconut oil and copra is tabingga. Tabingga is a coir and coconut shell that is still united. In addition, one of the waste which has not been utilized is corn cobs. Therefore, researchers are interested in utilizing, bio-tabs, and corn cobs as alternative energy sources. The purpose of this study was to study the effectiveness of tabingga briquettes and corn cob briquettes. This research uses an experimental method. Biomass are processed into briquettes by using a variation of the adhesive percentage of 5\%,10\% and $15 \%$. Briquette quality testing was carried out at the University of Tadulako Chemistry laboratory. The study was conducted from May to August 2019. The results showed that for the calor assessment, both briquettes did not meet SNI requirement. for water content only corn cob briquettes with $5 \%$ and $10 \%$ percentages were in accordance with SNI requirements, suitable for ash content, the content of the volatile substance and the second carbon content meet the SNI requirements.
\end{abstract}

Keywords :Tabingga briquettes, corn cob briquettes, bio Arang, biomass, alternative energy sources

\begin{abstract}
Abstrak
Salah satu cara untuk mengatasi masalah krisis energi adalah dengan menemukan energi alternatif yang berasal dari biomassa. Sulawesi Tengah merupakan salah satu daerah penghasil buah kelapa. Kelapa diolah untuk dijadikan minyak kelapa dan kopra. Limbah buangan dari usaha minyak kelapa dan kopra tersebut adalah tabingga. Tabingga merupakan sabut dan tempurung kelapa yang masih menyatu. Selain itu, salah satu limbah buangan yang juga belum termanfaatkan adalah tongkol jagung. Oleh karenanya peneliti tertarik untuk meneliti efektivitas briket bioarang tabingga dan tongkol jagung sebagai sumber energi alternatif. Tujuan penelitian ini adalah untuk mengetahui keefektifitasan briket tabingga dan briket tongkol jagung. Penelitian ini menggunakan metode ekperimen. Biomassa diolah menjadi briket dengan menggunakan variasi persentase perekat $5 \%, 10 \%$ dan $15 \%$. Pengujian mutu briket dilakukan di laboratorium Kimia Universitas Tadulako. Penelitian dilakukan dari bulan Mei sampai Agustus tahun 2019. Hasil penelitian menunjukkan bahwa untuk nilai kalor pembakaran, kedua briket belum memenuhi syarat SNI, untuk kadar air hanya briket tongkol jagung dengan persentase 5\% dan $10 \%$ yang memenuhi syarat SNI, sedangkan untuk kadar abu, kadar zat yang menguap dan kadar karbon kedua briket memenuhi syarat SNI.
\end{abstract}

Kata kunci :briket tabingga , briket tongkol jagung, bioarang , biomassa, sumber energi alternative. 


\section{Pendahuluan}

Kebutuhan energi dunia terus meningkat, seiring dengan pertambahan jumlah penduduk. Aktivitas manusia yang membutuhkan bahan bakar turut andil dalam mempercepat berkurangnya jumlah energi, ditambah lagi dengan semakin menipisnya cadangan sumber energi bumi [5]. Salah satu cara untuk meminimalkan penggunaan sumber energi bumi dengan menemukan bahan-bahan yang dapat digunakan sebagai sumber energy alternatif, utamanya sebagai bahan bakar [3].

Adapun nilai kalor dari beberapa jenis bahan bakar ditunjukkan oleh Tabel berikut [1]:

Tabel 1.Nilai kalor rata-rata dari beberapa jenis bahan

\begin{tabular}{clc}
\multicolumn{2}{c}{ bakar } \\
\hline No. & \multicolumn{1}{c}{ Bahan Bakar } & Nilai Kalor (kal/g) \\
\hline 1 & Kayu & 4491,2 \\
2 & Batubara Muda & 1887,3 \\
3 & Batubara & 6999,5 \\
4 & Minyak Bumi & 10081,2 \\
5 & Bahan Bakar Minyak & 10224,6 \\
6 & Gas Alam & 9722,9 \\
\hline
\end{tabular}

Sedangkan nilai kalor yang diperoleh dari beberapa penelitian untuk briket dengan berbagai biomassa ditunjukkan pada tabel berikut [4]:

Tabel 2.Nilai kalor dari beberapa briket biomassa

\begin{tabular}{clc}
\hline No. & \multicolumn{1}{c}{ Bahan Bakar } & Nilai Kalor $(\mathbf{k a l} / \mathbf{g})$ \\
\hline 1 & Briket Arang Sekam & 3520 \\
2 & Briket Alang-alang & 3883 \\
3 & Briket serbuk Gergaji & 4432 \\
4 & Briket Arang & 4822 \\
& $\begin{array}{l}\text { Bonggol Jagung } \\
5\end{array}$ & $\begin{array}{l}\text { Briket Arang Kayu } \\
\text { dan tempurung }\end{array}$ \\
& Kelapa \\
6 & $\begin{array}{l}\text { Briket campuran } \\
\text { kayu, bamboo, sabut } \\
\text { kelapa dan } \\
\text { tempurung kelapa }\end{array}$ \\
\hline
\end{tabular}

Sulawesi Tengah merupakan salah satu Provinsi penghasil buah kelapa. Buah kelapa yang sudah tua, biasanya diolah menjadi minyak kelapa, santan, dan kopra. Tabingga merupakan hasil sampingan dan buangan dari limbah para pengusaha minyak kelapa dan kopra. Tabingga biasanya digunakan oleh masyarakat di Sulawesi Tengah sebagai bahan bakar dalam proses pembuatan batu bata/batu merah. Karena produktivitasnya yang tinggi, maka tabingga belum banyak dikaji nilai tambahnya.Begitupun halnya dengan tongkol jagung yang biasanya hanya dimanfaatkan sebagai pakan ternak.

Berdasarkan hal tersebut, maka peneliti tertarik untuk mengetahui keefektifitasan briket tabingga dan tongkol jagung. Oleh karenanya dilakukan pengujian untuk mengetahui kadar air, kadar abu, kadar zat yang menguap (volatile matter) dan kadar karbon dari masing-masing briket tersebut.

\section{Metoda Penelitian}

\subsection{Jenis Penelitian}

Penelitian ini merupakan penelitian eksperimen. Penelitian dilakukan mulai bulan Mei sampai Agustus 2019. Pengujian sampel dilakukan di Laboratorium Kimia FMIPA Universitas Tadulako.

\subsection{Objek Penelitian}

Objek dalam penelitian ini adalah briket tabingga dan briket tongkol jagung dengan variasi perekat sebesar 5\%, 10\% dan $15 \%$. Massa total arang sebesar 200 gram yang dicetak pada cetakan ukuran diameter 5 $\mathrm{cm}$, tinggi $7 \mathrm{~cm}$.

\section{Hasil Penelitian}

Briket tabingga dan briket tongkol jagung yang telah dikeringkan, kemudian diuji di laboratorium untuk mengetahi nilai kalor, kadar air, kadar karbon, kadar abu, dan kadar zat yang menguap (volatile matter). Adapun hasilnya adalah sebagai berikut:

\subsection{Pengujian Nilai Kalor}

Pengujian nilai kalor menggunakan alat calorimeter bom. Hasil yang diperoleh sebagai berikut: 


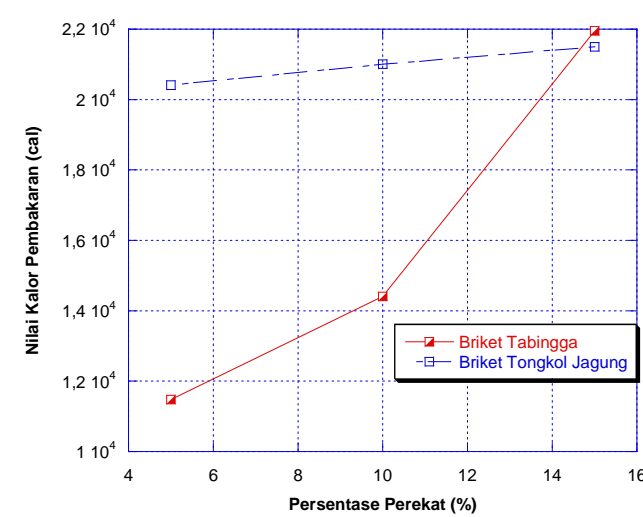

Gambar 1. Hubungan antara Konsentrasi Perekat dengan Nilai Kalor Pembakaran Briket

Gambar 1 menunjukkan bahwa, briket yang memiliki persentase perekat lebih banyak, menyebabkan komposisi briket semakin padat dan dapat menghasilkan nilai kalor yang lebih tinggi. Jika kedua briket dibandingkan, untuk persentase perekat $5 \%$ dan $10 \%$, briket tongkol jagung memiliki nilai kalor pembakaran yang lebih tinggi dibandingkan briket tabingga. Tetapi untuk persentase perekat $15 \%$, briket tabingga menghasilkan nilai kalor pembakaran yang lebih besar dibandingkan dengan briket tongkol jagung. Hasil penelitian ini jika dibandingan dengan nilai SNI sebesar 5000 cal/gr [2], maka kedua briket dinyatakan belum memenuhi syarat SNI.

\subsection{Pengujian Kadar Air}

Pengujian kadarairmenggunakan ASTM D7582-12. Adapun hasil yang diperoleh adalah:

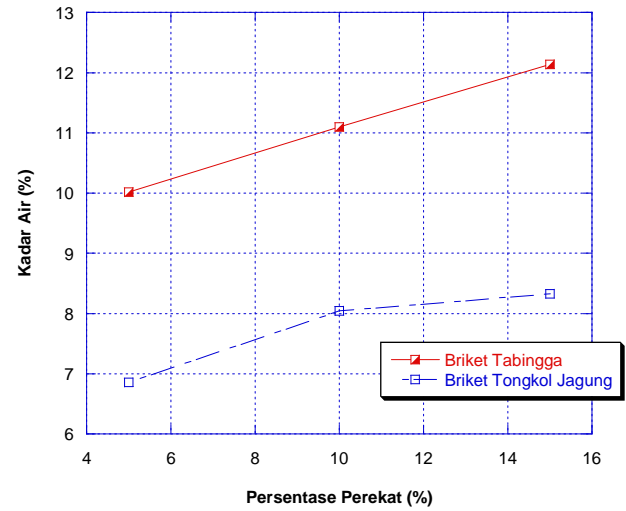

Gambar 2. Hubungan antara Persentase Perekat dengan Kadar Air Briket

Berdasarkan gambar 2, kadar air tertinggi untuk briket tabingga sebesar $12,136 \%$ diperoleh untuk persentase perekat $15 \%$. Sedangkan kadar air terendah sebesar
$10,018 \%$ diperoleh untuk persentase perekat 5\%. pada briket tongkol jagung, kadar air tertinggi sebesar 8,329\% diperoleh dari persentase perekat $15 \%$. Sedangkan kadar air terendah sebesar $6,857 \%$ diperoleh untuk persentase perekat $5 \%$.

Briket dengan perentase perekat lebih banyak, menyebabkan komposisi briket semakin padat dan lebih banyak menyerap air. Jika kedua briket dibandingkan, maka briket tabingga sifatnya lebih menyerap air dibandingkan dengan briket tongkol jagung. Hal ini disebabkan oleh bahan penyusun briket tabingga yang didominasi oleh sabut kelapa yang lebih mudah menyimpan air. Kadar air yang tinggi ini akan mengakibatkan briket tabingga sulit terbakar dan menghasilkan nilai kalor yang rendah. Jika briket dibandingkan dengan standar SNI dimana persentase kadar air yang diterima $\leq$ $8 \%$ [2], maka hanya briket tongkol jagung dengan persentase perekat $5 \%$ dan $10 \%$ yang memenuhi syarat.

\subsection{Pengujian Kadar Abu}

Pengujian kadar abu menggunakan ASTM D7582-12. Adapun hasil yang diperoleh adalah:

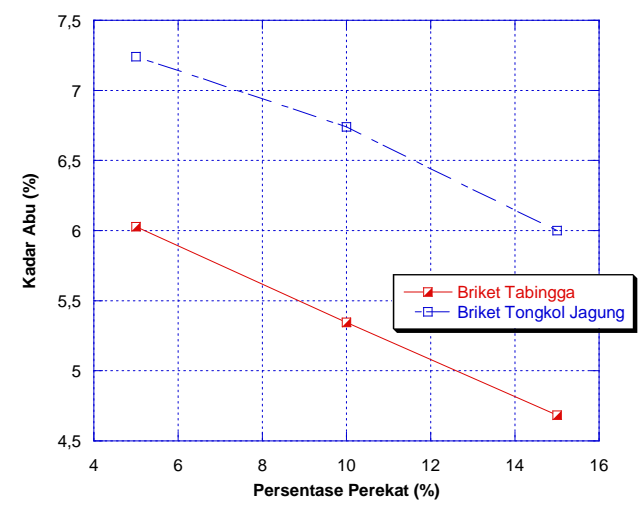

Gambar 3. Hubungan Persentase Perekat dengan Kadar Abu Briket

Berdasarkan gambar 3, kadar abu tertinggi untuk briket tabingga sebesar $6,028 \%$ diperoleh dari persentase perekat $5 \%$, dan kadar abu terendah sebesar 4,684\% untuk persentase perekat $15 \%$. Sedangkan pada briket tongkol jagung, kadar abu tertinggi sebesar $7,241 \%$ diperoleh dari persentase perekat $5 \%$, dan untuk kadar abu terendah sebesar $6,001 \%$ untuk persentase perekat $15 \%$. Hal ini menunjukkan bahwa, 
briket yang memiliki persentase perekat lebih banyak, menyebabkan kadar abu pada briket semakin menurun.

Jika kedua briket dibandingkan, maka briket tongkol jagung memiliki kadar abu lebih tinggi dibandingkan briket tabingga. Hal ini disebabkan oleh komposisi serat tongkol jagung 23,74\% lignin, $65,96 \%$ selulosa dan 10,28\% hemiselulosa [3]. Dan jika dibandingkan dengan standar SNI untuk kadar abu yang diterima $\leq 8 \%$ [2], maka kedua briket dinyatakan memenuhi syarat SNI.

\subsection{Pengujian Kadar Zat yang Menguap}

Pengujian kadar zat yang menguap menggunakan ASTM D7582-12. Adapun hasil yang diperoleh adalah:

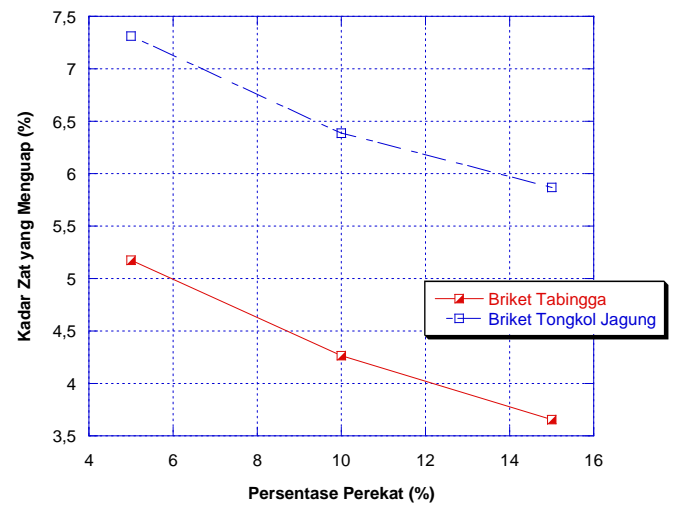

Gambar 4. Hubungan Persentase Perekat dengan Kadar Zat yang menguap

Berdasarkan gambar 4, kadar zat menguap tertinggi pada briket tabingga sebesar $5,173 \%$ untuk persentase perekat $5 \%$, dan kadar zat menguap terendah sebesar $3,655 \%$ untuk persentase perekat $15 \%$. Sedangkan pada briket tongkol jagung, persentase kadar zat menguap tertinggi sebesar 7,311\% untuk persentase perekat $5 \%$, dan kadar zat menguap terendah sebesar $5,870 \%$ untuk persentase perekat $15 \%$.

Semakin tinggi persentase perekat, menyebabkan kadar zat yang menguap semakin menurun. Dan jika kedua briket dibandingkan, maka briket tongkol jagung memiliki kadar zat yang menguap lebih tinggi dibandingkan briket tabingga. Hal ini terbukti dengan banyaknya asap yang dihasilkan pada saat proses pembakaran. Dan jika dibandingkan dengan standar SNI untuk kadar zat yang menguap yang diterima $\leq$
$15 \%$ [2], maka kedua briket dinyatakan mememenuhi syarat SNI.

\subsection{Pengujian Kadar Karbon}

Pengujian kadar karbon menggunakan ASTM D7582-12. Adapun hasil yang diperoleh adalah:

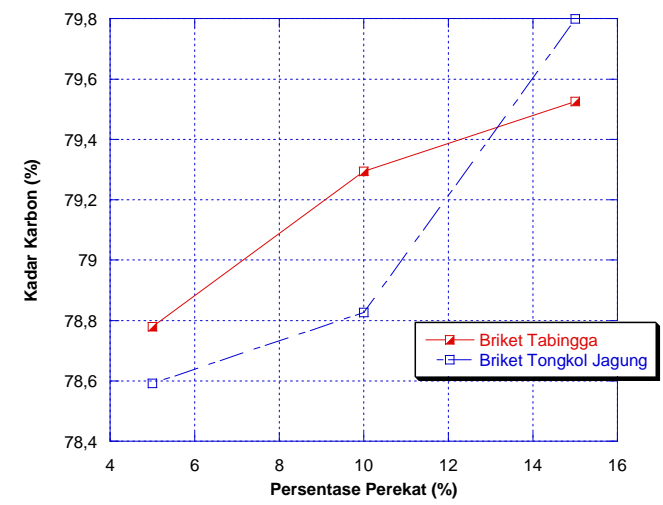

Gambar 5. Hubungan Persentase Perekat dengan Kadar Karbon Briket

Berdasarkan gambar 5, kadar karbon tertinggi untuk briket tabingga sebesar $79,525 \%$ untuk persentase perekat $15 \%$. Sedangkan kadar karbon terendah sebesar $78,780 \%$ untuk persentase perekat $5 \%$. Sedangkan pada briket tongkol jagung, kadar karbon tertinggi sebesar 79,799\% untuk persentase perekat $15 \%$. Sedangkan untuk kadar karbon terendah sebesar $78,592 \%$ pada persentase perekat $5 \%$.

Briket yang memiliki persentase perekat lebih banyak, menyebabkan kadar karbon semakin meningkat. Dan jika kedua briket dibandingkan, pada persentase perekat $5 \%$ dan 10\%, briket tongkol jagung menghasilkan kadar karbon yang lebih rendah dibanding briket tabingga. Hal inilah yang menyebabkan pada briket tongkol jagung menghasilkan asap yang lebih banyak dan juga menghasilkan bau [6]. Berbeda halnya pada persentase perekat $15 \%$, briket tongkol jagung tidak menghasilkan asap dan tidak menimbulkan bau. Dan jika dibandingkan dengan standar SNI untuk kadar karbon yang diterima $\geq 77 \%$ [2], maka kedua briket dinyatakan memenuhi syarat SNI. 


\section{Kesimpulan}

Berdasarkan dari hasil penelitan yang telah dilakukan, diperoleh bahwa:

1. Berdasarkan nilai kalor pembakaran, briket tabingga dan briket tongkol jagung belum memenuhi syarat SNI.

2. Berdasarkan kadar airnya, hanya briket tongkol jagung dengan persentase 5\% dan $10 \%$ yang memenuhi syarat SNI.

3. Berdasarkan kadarabunya, kedua briket memenuhi syarat SNI.

4. Berdasarkan kadar zat yang menguap, kedua briket memenuhi syarat SNI.

5. Berdasarkan kadar karbon, kedua briket memenuhi syarat SNI.

\section{Saran}

Untuk meningkatkan nilai kalor yang dimiliki oleh briket tabingga dan briket tongkol jagung, disarankan untuk menambah waktu penjemuran bahan, agar bahan benarbenar kering

\section{Ucapan Terima Kasih}

Penulis mengucapkan banyak terimakasih kepada: Kementerian Riset, Teknologi dan Pendidikan Tinggi yang telah membantu membiayai penelitian ini melalui kegiatan Riset DRPM tahun anggaran 2019.

\section{Daftar Pustaka}

[1] Amalinda F dan Jufri M, "Formulasi Briket Bioarang Sekam Padi dan Biji Salak Sebagai Sumber Energi Alternatif", Jurnal Sains Terapan., vol. 4, no, 2, pp 99-103,2018.

[2] Anggoro D.D, Hanif M.D, Fathoni M.Z, "Pembuatan Briket Arang dari campuran Tempurung Kelapa dan Serbuk gergji Kayu Sengon", Jurnal Teknik, Vol. 38 no. 2, pp76-80, 2017.

[3] Aryani N.P, Masturi, Edie S.S, "Pengembangan Briket Bonggol Jagung sebagai Sumber Energi Terbarukan," Jurnal MIPA, vol. 40 no. 1, pp. 20-23, 2017.

[4] Manik F.S, "Pemanfaatan Spent Bleaching Earth dari Proses Pemucatan CPO Sebagai Bahan baku Briket", Skripsi, IPB: Bogor, 2010.

[5] Nuriana W, Suryanto A and Kamal M, "Calorific value analysis, reduction of period weight, reaction rate, activation energy of old coconut, young coconut waste briquette burning, cocoa," IOP conference series: Material Science and Engineering 588 (2019) 012004.

[6] Sulistyaningkarti. L, dan Utami. B, "Pembuatan Briket Arang dari Limbah Organik Tongkol Jagung Dengan Menggunakan Variasi Jenis dan Persentase Perekat", Jurnal Kimia Dan Pendidikan Kimia, vol. 2, no. 1, pp 43-53, 2017. 
